\title{
UMA LEITURA DAS ORGANIZAÇÕES CRIMINOSAS, A PARTIR DA LEGISLAÇÃO DE EMERGÊNCIA
}

\author{
Emílio de Oliveira e Silva* \\ Felipe Daniel Amorim Machado**
}

\section{RESUMO}

O fenômeno da globalização provocou sensíveis modificações no âmbito político, econômico, social e cultural em todo o mundo. Tais transformações repercutiram no crime organizado que desenvolveu métodos mais eficientes e seguros na prática de infrações penais, o que o tornou um dos grandes desafios a ser enfrentado pelo Estado na atualidade. Nesse contexto, uma das grandes tendências de tratamento jurídico às organizações criminosas é a sua criminalização. O presente trabalho visa analisar o conceito de crime organizado, abordando sua origem como típica de uma legislação de emergência, além de criticar o despreparo do direito brasileiro para lidar com bens jurídicos metaindividuais, como é o caso do bem jurídico atacado pelas organizações criminosas.

Palavras-chave: Globalização. Organizações criminosas. Crime organizado. Legislação de emergência.

\footnotetext{
* Mestrando Direito Processual (PUC Minas); Especialista em Ciências Penais (IEC/PUC Minas); Delegado de Polícia Civil (MG).

** Mestrando em Direito (UFMG); Especialista em Ciências Penais (IEC/PUC Minas); Fundador e atual Diretor-Presidente do Instituto de Hermenêutica Jurídica (IHJ); Estagiário de Docência em Direito Penal (UFMG); Professor Substituto de Processo Penal (UFOP); Advogado (OAB/MG).
} 


\begin{abstract}
The phenomenon of globalization has caused sensitive changes in the political, economic, social and cultural development worldwide. These changes had an impact on organized crime that has developed more efficient and safe methods in the practice of criminal offenses, which became one of the major challenges being faced by the State today. In this context, one of the major trends in legal treatment of criminal organizations is its criminalization. This study aims to examine the concept of organized crime by addressing its origin as a typical emergency legislation, while criticizing the lack of knowledge of Brazilian law to deal with metaindividual rights such as the legal attacked by criminal organizations.
\end{abstract}

Key-words: Globalization. Criminal organizations. Organized crime. Emergency legislation.

\title{
APORTES INICIAIS
}

O progresso da sociedade contemporânea, impulsionado pela globalização, que rompeu as fronteiras dos países não só a mercancias, mas também a pessoas e informações, "experimenta novas modalidades de criminalidade que ultrapassam as fronteiras dos Estados nacionais" ${ }^{1}$. A lavagem de dinheiro, o narcotráfico, a ameaça terrorista e o tráfico de pessoas, crianças e órgãos compõem uma criminalidade que surgiu nas legislações a partir da segunda metade do séc. XX, intensificando-se na última década desse mesmo século e ganhando ainda mais força no início do séc. XXI em um movimento denominado de "expansão do Direito Penal" 2 .

Esse novo tipo de criminalidade é impraticável sem o emprego de redes logísticas e de comunicação, o que configura sofisticadas estruturas organizacionais ${ }^{3}$. Logo, em termos de globalização, alguns desses grupos dirigidos ao crime organizado possuem um poder maior que os próprios Estados, ou então escapam ao seu controle políticojurídico, safando-se, em consequência, da persecução e punição por seus delitos ${ }^{4}$.

Face a ineficiência da persecução estatal diante das organizações 
criminosas, aumentou o sentimento de impunidade e medo da sociedade, o que gerou perversão, rejeição e segregação em face daqueles que eventualmente cometeram este determinado tipo conduta. A fim de sanar o problema dessa emergência penal, o Estado passou a utilizar-se de medidas excepcionais no intuito de dar uma resposta firme aos anseios punitivos do corpo social. Tais ações geralmente se caracterizam pelo endurecimento da legislação penal, traduzida na criminalização de um maior número de condutas e no desproporcional aumento das penas, além da majoração dos poderes policialescos de investigação e na mitigação de garantias e direitos fundamentais do cidadão. Essas medidas extraordinárias compõem uma corrente que cresce a largos passos no discurso jurídico-político criminal contemporâneo denominada Direito Penal do inimigo (Feindstrafrecht).

Nesse contexto, um dos grandes desafios do Direito Penal é o tratamento jurídico desse dito crime organizado. A tipificação penal dessas organizações criminosas surge como uma das principais propostas para a prevenção e combate dessa modalidade criminosa ${ }^{5}$. Não obstante, essa criminalização encontra sérias objeções no Estado Democrático de Direito, especialmente quando se discute os limites de um Direito Penal do fato.

O presente trabalho visa analisar o crime organizado, abordando as principais questões referentes à tipificação penal das organizações criminosas. Para tanto, contextualiza-se o crime organizado dentro de uma nova ordem mundial, marcada pela globalização, para então explicar a crescente inclinação político-criminal de emergência para o enfrentamento daquele tipo de criminalidade.

\section{CRIME ORGANIZADO NA NOVA ORDEM MUNDIAL}

\section{A GLOBALIZAÇÃO}

Após a Segunda Guerra Mundial, o mundo passou por diversas transformações provocadas pelo início e fim da Guerra fria, pela queda do muro de Berlim, além da expansão do capitalismo e sua respectiva influência sobre a abertura dos mercados mundiais. 
A onda expansionista do ocidente sobre o oriente na busca por novos mercados, com o estímulo cada vez maior pelo consumo, requereu uma nova formatação do próprio mercado, com a radicalização de suas próprias estruturas, o chamado neo-capitalismo, necessitando, por sua vez, da flexibilização das barreiras, com vistas a facilitar a transição de mercadorias, capitais e pessoas. ${ }^{6}$

Assim, sob o argumento de que esse rompimento de barreiras seria necessário ao desenvolvimento econômico e social das nações, principalmente daquelas subdesenvolvidas, surge o movimento de (des)integração mundial chamado de globalização.

O conceito de globalização também é tormentoso, recebendo conceitos diferentes a partir do referencial teórico de quem o define. Leonardo Boff 7 , por exemplo, vê a globalização como um fenômeno eminentemente econômico-financeiro que modificou as relações entre pessoas e afetou diretamente o planeta. Para o autor, a globalização é marcada por uma "economia de mercado que transformou tudo em mercadoria em função do ganho e que criou uma sociedade de mercado e não uma sociedade com mercado".

Por sua vez, Barbosa ${ }^{8}$ afirma que a globalização se caracteriza pela expansão dos fluxos de informações em todos os países e setores (indivíduos, empresas e movimentos sociais), pela celeridade das transações econômicas nacionais e internacionais e pela "crescente difusão de valores políticos e morais em escala universal”.

O liame de todas as conceituações de globalização pode ser identificado no desenvolvimento econômico e tecnológico. De fato, o desenvolvimento tecnológico dos meios de comunicação, por exemplo, encurtou distâncias e permitiu que acontecimentos do outro lado do planeta fossem acompanhados em tempo real pela televisão, computadores ou mesmo pelo celular. O surgimento da própria internet abriu novos mercados e propiciou a criação de uma enorme rede de informações, trazendo impactos políticos e culturais em todo o mundo. As empresas não têm mais raízes nos seus países de origem: adquiriram mobilidade suficiente para instalarem-se em novas regiões, conforme a estabilidade econômica, o custo de produção e o mercado consumidor. Há uma acentuada tendência de fusões e aquisições de grandes sociedades empresariais. 
Com a globalização, houve uma redistribuição de poderes dentro de uma nova hierarquia global ${ }^{9}$. No que toca ao Estado, este foi diretamente afetado na sua soberania, muitas vezes relativizada com a criação de mercados econômicos transnacionais, tratados e convenções internacionais. Em verdade, as maiores beneficiárias da globalização foram/são, de fato, as empresas privadas, eis que "das 100 (cem) maiores economias mundiais, 51 (cinquenta e uma) são empresas multinacionais e 49 (quarenta e nove) são Estados nacionais"10.

Zygmunt Bauman adverte sobre a crescente dominação do Estado pelo mercado financeiro, que vem atualmente pautando as políticas estatais, defendendo que:

Devido à total e inexorável disseminação das regras de livre mercado e, sobretudo, ao livre movimento do capital e das finanças, a 'economia' é progressivamente isentada do controle político; com efeito, o significado primordial do termo 'economia' é o de 'área não política'. O que quer que restou da política, espera-se, deve ser tratado pelo Estado, como nos bons velhos tempos - mas o Estado não deve tocar em coisa alguma relacionada à vida econômica: qualquer tentativa nesse sentido enfrentaria imediata e furiosa punição dos mercados mundiais. A impotência econômica do Estado seria então mais uma vez flagrantemente exposta pra horror da equipe governante. ${ }^{11}$

Este é o cenário atual: "o significado mais profundo transmitido pela ideia da globalização é o do caráter indeterminado, indisciplinado e de autopropulsão dos assuntos mundiais (...). A globalização é a "nova desordem mundial'"12 que leva "ao recuo da política e à falência dos grandes sistemas de sentido" 13

\section{CRIME ORGANIZADO NO CONTEXTO GLOBALIZADO: O BEM JURÍDICO METAINDIVIDUAL}

Acompanhando o desenvolvimento das estruturas sociais, a criminalidade, como produto dessas mesmas sociedades, não fugiu à sua lógica, modificando suas estruturas e formas de atuação para adequálas a esta nova realidade. Logo, as antigas ferramentas utilizadas pelo Estado no seu combate passaram a não surtir mais efeitos. 
Nesse quadro, as organizações criminosas surgem como uma nova preocupação social que abala o modelo de repressão e prevenção à criminalidade tradicional. Aponta-se que tal fato se deve à globalização que desregulamenta mercados, flexibilizando suas barreiras, internacionaliza a economia e provoca um progresso vertiginoso da informática e da comunicação. Callegari ${ }^{14}$ afirma que a "criminalidade organizada é a da globalização", caracterizando-a como um novo fenômeno cujas origens se devem à "expansão internacional da atividade econômica e a abertura ou globalização dos mercados".

No contexto globalizado, o crime organizado busca maiores ganhos com mínimos riscos, de modo que seu modus operandis prioriza o emprego de métodos sofisticados no empreendimento delitivo, deixando, em segundo plano, o uso da força e violência ${ }^{15}$. De fato, a sofisticação das organizações criminosas as transformou em um dos negócios mais lucrativos do planeta. Estudos das Organizações das Nações Unidas (ONU) apontam que o narcotráfico aufere por ano cerca de US\$ 400 bilhões em todo o mundo, o que equivale a $8 \%$ do comércio internacional e "mais do que todas as exportações de ferro e aço, da indústria automobilística ou da têxtil"16. Outro dado significativo que revela a dimensão das cifras movimentadas pelo crime organizado é o de que a máfia italiana teria cooptado a ilha caribenha de Aruba com recursos provindos do tráfico de drogas praticado nos Estados Unidos da América na década de $1980^{17}$.

O sucesso dessa atividade delituosa exige estruturas financeiras que permitam movimentar grandes quantias de valores sem a detecção dos órgãos estatais de fiscalização. Daí porque o Conselho de Controle de Atividades Financeiras ${ }^{18}$ defende que as atenções para as organizações criminosas devem se voltar para o seu aspecto financeiro. Neste contexto, o Grupo de Egmont ${ }^{19}$ analisou 100 (cem) casos típicos de lavagem de dinheiro. Divididas em categorias, constatou-se que os principais métodos praticados pelo crime organizado na formalização de capitais podem ser classificados da seguinte forma: (i) ocultação de recursos oriundos de atividade delitiva dentro de sociedades empresárias; (ii) utilização indevida de empresas legítimas; (iii) uso sistemático de documentos falsos e de nomes de terceiros (testas-de-ferro/laranjas); (iv) uso de ativos ao portador; (v) uso eficaz de intercâmbio de informações da área de inteligência. 
Contudo, para além da lavagem de capitais, o crime organizado vem se valendo da infiltração de seus membros dentro de órgãos estatais ${ }^{20}$. Essa penetração no âmbito do próprio Estado, segundo Gomes $^{21}$, poderia ser praticada através de duas maneiras. A primeira é uma forma indireta de conexão que se divide em: (1.i) financiamento de campanhas políticas que visa instaurar um sistema de reciprocidade no qual a oferta de recursos financeiros eleitorais retorne através de apoio às atividades das organizações criminosas; (1.ii) corrupção "que se dá através do pagamento em dinheiro de suborno ou propina, para a obtenção de atos favoráveis, por parte de funcionários públicos, e que são estranhos ao seu dever legal". A segunda seria a chamada de "formas diretas de conexão", que podem ser classificadas em três ${ }^{22}$ : (2.i) Inserção direta de componentes da organização criminosa na estrutura do Estado, a fim de aproximar as esferas pública e privada, obtendo, assim, conhecimentos das operações administrativas, além de criar e fortalecer contatos e relações com autoridades públicas para o favorecimento de empresas privadas. (2.ii) Uso de intermediários, sendo que este não integraria a estrutura estatal, agindo com neutralidade e aparentemente dentro da legalidade. Geralmente é um profissional específico da área na qual se passa a operação que formalizará o capital ilícito, intervindo no Estado em prol do crime organizado. (2.iii) Formação da organização criminosa dentro do Poder Público ${ }^{23}$.

Outra reflexão que merece destaque é a de Raúl Cervini ${ }^{24}$ para quem as organizações criminosas mantêm estratégias criminais flexíveis, atendendo a uma concepção geocêntrica. Assim, suas ramificações ou células operacionais se dividem em distintas regiões, inclusive fora do país, estando aptas a responder, prontamente, às exigências mercadológicas territoriais.

Diante da complexidade de sua organização, bem como da lucratividade de suas ações, percebe-se que o crime organizado foca sua ação em bens jurídicos que transcendem ao indivíduo singular, bem como a um Estado visto isoladamente. Assim, na formalização (lavagem) do capital, fruto de suas atividades ilícitas, acaba-se por atacar sistemas econômicos, ou seja, infringe um bem jurídico metaindividual. Logo, o crime organizado, principalmente quando age sobre a delinquência econômica, investe-se contra um bem jurídico metaindividual, qual seja, a ordem socioeconômica do Estado. Nesse sentido, aduz Callegari 
quando se defrauda a previdência, o Fisco, etc., o Estado se fragiliza e passa a não prestar um bom serviço. É evidente que tais conseqüências têm repercussão na vida e na integridade física das pessoas, porém, não de maneira direta como na comissão da maioria dos delitos tradicionais em que a repercussão aparece, normalmente, em seguida. ${ }^{25}$

Portanto, fácil é a percepção de que o modo de agir das quadrilhas ou bandos, figuras típicas previstas no art. 288 do Código Penal brasileiro, foram superadas por complexas atividades criminosas que, não raro, atuam internacionalmente. Contudo, no Brasil, ainda prevalece uma legislação penal voltada à tutela de bens jurídicos interindividuais, logo, sem uma construção dogmática consistente na tutela de direitos supra-individuais ${ }^{26}$.

Registre-se, por fim, que "seja pelas técnicas empregadas, seja pelos meios de que dispõem ou pelos imensos danos visíveis ou não que causam" 27 as atividades praticadas pelo crime organizado potencializaram os danos sociais, violando, sistematicamente, bens jurídicos individuais, coletivos e difusos. Por todos esses motivos, o crime organizado se tornou um dos principais focos de insegurança na sociedade $^{28}$. Trata-se de um problema real e em expansão, cujos estudos ainda trilham os passos iniciais na explicação do fenômeno.

\section{BREVE PANORAMA SOBRE DIFERENTES TIPOS DE CRIMINALIDADE}

Conciliar eficiência com respeito às garantias fundamentais é a finalidade e o desafio do sistema penal. Logo, a fim de alcançar tal objetivo, dever-se-ia franquear ao Estado a "adoção de medidas excepcionais de restrição a direitos individuais em relação ao crime organizado" cuja aplicação deveria, obrigatoriamente, obedecer às garantias fundamentais constitucionais do indivíduo ${ }^{29}$. Com base nesse pensamento, Scarance ${ }^{30}$ propõe que a criminalidade seja dividida em três grupos: (i) criminalidade leve ou de bagatela; (ii) criminalidade comum; (iii) criminalidade grave ou organizada.

A criminalidade de bagatela estaria ligada às infrações penais leves. Tendo em vista o baixo potencial ofensivo da criminalidade de 
bagatela, são feitas algumas propostas para a resolução deste problema no âmbito do direito penal e processual penal, tais como: (i) evitar a instauração do processo, aumentando-se o rol dos crimes dependentes de representação ou prevendo-se a transação penal; (ii) impedir a imposição de pena, mediante a suspensão do processo sob condições durante certo período e, decorrido o prazo sem revogação, pela consequente extinção de punibilidade; (iii) evitar a imposição de pena privativa de liberdade com a aplicação de penas restritivas de direitos ou pecuniárias; (iv) possibilitar ao condenado o não cumprimento em cárcere da pena privativa de liberdade, suspendendo-a ou admitindo o seu cumprimento em domicílio ou em albergue" ${ }^{\prime \prime}$.

De outro lado, surge a criminalidade comum, cujo tratamento é feito pelo sistema penal e processual penal tradicional, "com ampla garantia às partes, com regime progressivo de pena, com prisão processual excepcional" ${ }^{\prime \prime 2}$.

Por fim, Scarance Fernandes ${ }^{33}$ ressalta que o tipo de criminalidade mais problemático tanto para o legislador quanto para a doutrina tem sido a criminalidade grave ou organizada que, por sua vez, pode ser dividida em três espécies, sendo elas: (i) a criminalidade grave, violenta e não organizada, dirigida a bens individuais como, por exemplo, o homicídio, o roubo, o estupro; (ii) a criminalidade grave, violenta ou não, não organizada, que atinge grupos de pessoas ou a coletividade como, por exemplo, o envenenamento da água potável, o induzimento ao suicídio coletivo, os golpes financeiros; (iii) a criminalidade organizada, cujas características não foram ainda bem definidas e que se manifesta no mundo por meio de modelos mafiosos, de entorpecentes, por grupos dedicados ao tráfico internacional de armas, de mulheres, de crianças, de animais, dentre outros.

A classificação da criminalidade, a partir da gravidade da lesão ou do perigo de lesão a bens jurídicos, revela-se legítima, pois a própria CRFB/1988, ao assegurar proteção ao indivíduo, também determinou que algumas espécies de crimes fossem tratados de forma mais gravosa, tal como ocorre com a tortura, o tráfico ilícito de entorpecentes, drogas e afins, o terrorismo, os crimes hediondos, o racismo e as ações de grupos armados contra a ordem constitucional e o Estado Democrático (art. $5^{\circ}$, XLII, XLIII e XLIV, todos da CFRF/88). O que é necessário 
salientar, entretanto, é que esse tipo de classificação não pode servir de fundamento para suprimir direitos e garantias fundamentais que não foram excepcionadas pelo legislador constituinte.

Em outra perspectiva, Hassemer ${ }^{34}$ ressalta a necessidade da distinção que deve ser feita entre a criminalidade de massa e a organi$z a^{35}$. Isso porque o discurso político ventilado pela mídia induz a população a crer que, atualmente, os grandes investimentos em sede de segurança pública são destinados ao combate do crime organizado. Isso, do ponto de vista político-criminal, pode ser um erro, na medida em que o sentimento de insegurança da população está mais relacionado à criminalidade de massas do que ao crime organizado.

Quanto aos crimes de colarinho branco (white-collar crime), atribuem-se ao sociólogo Edwin Sutherland as primeiras pesquisas sobre tais tipos de delitos. Segundo Baratta ${ }^{36}$, os estudos de Sutherland demonstravam um índice elevadíssimo de infrações relacionadas à economia e ao comércio praticadas por pessoas de prestígio pessoal que, entretanto, não eram contabilizados nas estatísticas oficiais, constituindo-se uma cifra negra da criminalidade.

Os crimes de colarinho branco são vinculados àqueles cometidos por pessoas de elevado status social no desempenho de alguma atividade ou profissão ${ }^{37}$. A referida expressão aplica-se aos delitos cometidos contra a economia, ordem tributária e financeira, bem como às infrações penais relacionadas à atividade empresarial, todas elas "fortemente marcadas pela impunidade, que implicam, ao lado do dano econômico, um dano de maior gravidade, imposto às relações sociais, pela geração de perda de confiança e produção de desorganização social em grande proporção" $38 /{ }^{39}$.

John Scheb e John Scheb II, citados por Ana Luiza Almeida Ferro ${ }^{40}$, defendem que a distinção entre os crimes de colarinho branco e o crime organizado está "na questão da mistura ou não entre atividades lícitas ou ilícitas e no emprego ou não de ameaças ou violência para a consecução do fim pretendido". Se é fato que nem todo crime de colarinho branco é praticado por uma organização criminosa, a assertiva contrária também é verdadeira. No entanto, a diferença entre esses dois fenômenos vem atenuando-se. A estruturação do crime organizado o obrigou, 
em maior ou menor escala, a enveredar-se para o mundo dos negócios empresariais, bem como para as negociatas políticas, sem as quais dificilmente teria sucesso na consecução de seus objetivos.

Da mesma forma que o crime organizado, o conceito de terrorismo é difícil de extrair-se, uma vez que ele "é dado pelos governos que tem interesse em persegui-lo, especialmente em dadas fases históricas, mais em bases políticas do que jurídicas" ${ }^{41}$. Mario Daniel Montoya ${ }^{42}$ relata que nos últimos tempos houve uma aproximação entre terroristas e organizações criminosas, o que resultou numa simbiose bem sucedida. "Por exemplo, os grupos terroristas aprenderam a lavar dinheiro e a fazer contrabando de produtos requeridos pelo mercado. Por sua vez, o crime aprendeu a funcionar com um sistema de células para aumentar a segurança de suas operações" ${ }^{\prime 3}$.

O terrorismo se distingue das demais formas de criminalidade porque seus atos têm duas principais finalidades: “(i) chamar a atenção da população (e da comunidade internacional) através de atos violentos; (ii) provocar mudanças políticas favoráveis aos seus pontos de vista" ${ }^{44}$. Todavia, alerta Ana Luiza Almeida Ferro ${ }^{45}$ que o crime organizado também pode se valer de atos violentos para atingir seus objetivos. Assim, a nota que distingue as organizações criminosas das organizações terroristas é "o seu caráter notadamente ideológico e subversivo do status quo, por intermédio de atos marcados pela tática do terror" ${ }^{\prime \prime 6} / 47$.

Outra distinção importante é aquela que diz respeito ao crime organizado e à máfia. A propósito, é impossível pensar na máfia e não se lembrar da Itália, na região da Sicília (localizada no sul da Itália), berço da Cosa Nostra, Camorra, N'Dranghetta e Sacra Corona Santa: as maiores e mais importantes organizações criminosas italianas ${ }^{48}$. A sua formação, modelo de constituição e o sucesso nos seus empreendimentos serviram de inspiração para outras organizações criminosas, motivo pelo qual se limitará à análise da máfia italiana, o que permite uma compreensão geral do modelo mafioso de organização criminosa.

Atribui-se o surgimento da máfia aos senhores feudais e príncipes habitantes da Sicília, Calábria, Campânia, Púglia e Basilicata que discordavam da ingerência do rei de Nápoles naquela região no início 
do século XIX. A gradativa redução de poderes dos senhores feudais do sul da Itália fez com que eles recorressem à contratação de "homens de honra" e estabelecessem "sociedades secretas - as máfias - para resistirem à investida real" 49 .

Posteriormente, já nas últimas décadas do século XIX, época na qual a Itália passava pelo processo de unificação, as máfias foram chamadas a atuar contra o "invasor estrangeiro piemontês", o que gerou um forte apelo popular por suas atividades. A partir dali, as máfias passaram a ser vistas como uma "instituição patriótica" 50

Segundo ${ }^{51}$, até a década de 80 do séc. XX, pouco se sabia sobre a Cosa Nostra, o que a tornava "misteriosa e indecifrável". Isso se devia à forma de organização da máfia que dificultava a ação estatal repressiva. Note-se que a linha de investigação contra as máfias concentrava-se nos autores materiais de cada delito, principalmente naqueles delitos de maior repercussão $\mathrm{o}^{52}$. "Assim, na melhor das hipóteses, aqueles que se conseguia individualizar e submeter à justiça eram os executores materiais dos crimes, jamais os chefes e/ou os mandantes, que continuavam a desfrutar da impunidade absoluta" ${ }^{53}$. Ao lado disso, acrescente-se a imposição da omertà (lei do silêncio) às pessoas que tinham conhecimento de algum fato praticado pela máfia.

A máfia é uma organização criminosa que se distingue das demais em razão de alguns valores que lhe são peculiares, tais como: (i) sentido de família; (ii) honra; (iii) cultura da morte; (iv) relação com o Estado e com o poder; (v) mito fundante; (vi) uso da violência; (vii) estrutura e organização ${ }^{54}$. Dentre esses fatores, o que chama atenção no modelo clássico de máfia é o cultivo à honra. Importante era que o mafioso fosse um homem de honra. Na maioria das vezes ele deveria passar por um rígido processo de seleção no qual se pudesse atestar sua confiabilidade e lealdade ao grupo.

Com os avanços alcançados pelos meios de comunicação e as novas relações de mercado surgidas a partir da segunda metade do século passado, as máfias tiveram que se adequar a essa realidade e reorganizar suas estruturas e táticas de ação, ainda que para isso tivessem que sacrificar parte de alguns valores do passado. Na Cosa Nostra o ingresso no mercado de drogas a fez rever sua logística de 
abastecimento e distribuição de produtos ilegais, o que provocou a expansão de suas fronteiras para outros países e a levou a uma aproximação com outras organizações criminosas. O sucesso obtido com esse novo negócio levou a máfia a um notável enriquecimento. As vultosas disponibilidades de capital passaram a ser empregadas no mercado financeiro e bancário, criando um novo perfil de máfia empreendedora $a^{55}$. A nova realidade experimentada pelos mafiosos foi decisiva para o abandono de parte de seus valores tradicionais. A ordem econômica global levou a máfia a desenvolver novas estruturas voltadas à economia capitalista e empresarial as quais nem sempre são compatíveis com o modelo mafioso clássico no qual o culto à honra era proeminente.

\section{CRIME ORGANIZADO: UMA CRISE CONCEITUAL}

A primeira dificuldade em compreender o crime organizado consiste em buscar uma terminologia tecnicamente adequada que identifique e caracterize o fenômeno. Não há, de fato, uma nomenclatura unívoca e universal sobre o tema. Ferro ${ }^{56}$ faz um apanhado das expressões empregadas pela doutrina nacional e estrangeira usadas como sinônimo da chamada "organização criminosa", sendo elas:

'associação criminosa', 'associação criminosa mafiosa', 'associação mafiosa', 'associação de modelo mafioso', 'associação criminosa de modelo mafioso', 'associação de tipo mafioso', 'associação organizada', 'associação ilícita', 'associação ilícita organizada', 'associação delinquencial especial', 'associação deliquencial complexa', 'organização criminal', 'organização de criminosos', 'organização do crime organizado', 'organização criminosa de tipo mafioso', 'organização criminosa de modelo mafioso', organização mafiosa', 'organização deliquencial', 'organização delitiva', 'organização delituosa', 'grupo organizado', 'grupo do crime organizado', 'grupo organizado criminoso', 'grupo criminoso organizado', 'grupo criminoso de origem mafiosa', 'grupo delituoso organizado', sodalício criminal', 'bando criminoso', 'empresa criminosa', 'multinacional criminosa', 'multinacional do crime organizado', 'sindicato criminoso', 'sindicato do crime', e 'entidade do crime organizado'

Muitas vezes essas terminologias são empregadas sem nenhum rigor técnico. Isso se agrava quando expressões como "organizações criminosas" e "crime organizado" são utilizadas como sinônimas de 
ações delituosas praticadas por gangues, bandos ou quadrilhas que nada ou pouco têm a ver com a criminalidade organizada strito sensu.

Na língua inglesa, há preferência pela nomenclatura organized crime, conquanto, no vernáculo francês, opta-se, preponderantemente, pela expressão criminalité organisée ${ }^{57}$. No Brasil, os termos mais utilizados são "crime organizado", "organização criminosa" e "criminalidade organizada". Fernando Salla", citando Fontanaud, diz que esta última expressão tem uma vantagem em relação às demais, uma vez que "crime se refere em língua latina à esfera dos comportamentos individuais", reportando-se à ideia de um "conjunto heterogêneo de crimes (cometidos ou sancionados) que ao mesmo tempo estão inseridos nos processos de confrontação social entre os mecanismos de controle e os atores delinquentes".

No entanto, há autores que criticam o emprego da expressão "criminalidade organizada", já que esta se refere, no campo sociológico, a um conjunto de crimes. É, portanto, nomenclatura genérica que engloba tanto o "crime organizado por natureza" quanto o "crime organizado por extensão" 59 .

Antônio de Moraes Pitombo ${ }^{60}$ defende o uso da terminologia "organização criminosa". Primeiro porque expressa melhor a distinção entre as meras associações de pessoas para a prática de crimes e a constituição de uma organização na qual há uma noção bem definida de cooperação e hierarquia entre os indivíduos que a compõem. Por fim, a palavra "organização" ressalta a "diferença entre organização criminosa e associações e sociedades do direito privado" ${ }^{61}$. Por sua vez, Ferro ${ }^{62}$ revela sua preferência pelas expressões "organização criminosa" e "crime organizado", eis que nelas se faz alusão a um dos elementos essenciais à compreensão do fenômeno, isto é, "o caráter de sofisticação estrutural, de certa complexidade na sua constituição, enfim, a sua organização" ${ }^{63}$.

A complexidade do fenômeno, contudo, não se atém à questão terminológica. Jorge de Figueiredo Dias ${ }^{64}$, por exemplo, assinala que as organizações criminosas podem ser encaradas sob vários aspectos, dentre eles os "sócio-filosóficos, sócio-econômicos, histórico-culturais, político-internacionais, político-criminais, criminológicos, ou, pura e 
simplesmente, políticos". De fato, muitas são as perspectivas a serem empregadas no conceito de crime organizado. Nota-se que a diversidade de definições sobre o tema provém dos diversos pontos de vista de encarar um mesmo fenômeno. Assim é que, conforme a referência que se adote - seja ela política, social, econômica ou cultural -, o conceito do crime organizado irá cambiar o seu sentido e, não raramente, poderá traduzir definições imprecisas, lacônicas ou mesmo contraditórias.

Nesse sentido, perceba-se que enquanto Hassemer ${ }^{65}$ encara a criminalidade organizada como um "fenômeno novo e excepcional", Juarez Cirino dos Santos ${ }^{66}$ visualiza no crime organizado "um antigo discurso do poder contra inimigos internos com diferentes denominações, como indicam situações históricas conhecidas". Sheila Jorge Selim de Sales ${ }^{67}$ aponta que grande parte dos estudos sociológicos estigmatizam o crime organizado de forma extremamente seletiva, deixando de abordar, por exemplo, a "macrocriminalidade econômica, em regra praticada nos corredores do poder econômico e do poder político". Na mesma linha de raciocínio, Fernando Salla ${ }^{68}$ denuncia a manipulação política da expressão crime organizado. No Brasil, ela vem adquirindo contornos político-criminais de identificação com as camadas pobres da população em detrimento das organizações criminosas de estruturação empresarial e política. A macrocriminalidade econômica, portanto, não recebe a "pecha de crime organizado, mas sim a de máfia: 'máfia dos fiscais' (1999), 'máfia dos combustíveis' (2005), 'máfia das sanguessugas' (2006)" 69 .

Portanto, percebe-se que a dificuldade para se definir o crime organizado ocorre porque mais que um problema criminal, a organização criminosa é um fenômeno sociológico, político e econômico que se modifica conforme o contexto histórico e cultural de uma sociedade ${ }^{70}$.

Zaffaroni, citado por Salim ${ }^{71}$, critica as tentativas em se conceituar o crime organizado, já que "a diversidade de fenômenos delituosos abarcados pela expressão 'crime organizado', omnicompreensiva de fatos que se pretende reduzir ad unum, na verdade, é falsa e tem sido o maior obstáculo para que se possa categorizá-la no âmbito científico". Dentro desta lógica, Cirino dos Santos ${ }^{72}$ defende a impossibilidade de comprovar-se a existência do crime organizado, uma vez que "conceitos sem validade científica não podem ser demonstrados". Logo, a 
depender do ponto de vista que se utilize, chegaremos a um conceito de crime organizado destinado a atender as premissas sociológicas, políticas, históricas ou culturais que o elaboraram.

Por fim, merece relevo a tentativa de conceituação do crime organizado presente na Convenção de Palermo ${ }^{73}$, especificamente em seu art. $2^{074}$. Numa decomposição da Convenção é possível concluir que "um grupo organizado" diz respeito a um grupo estável e estruturado, integrado por, ao menos, três indivíduos, que aja com intuito de cometer um ou mais crimes graves (de penas maior ou igual a quatro anos), objetivando a obtenção de vantagens econômicas ou materiais.

Parte dos membros da Organização das Nações Unidas (ONU) tinha que o conceito de crime organizado ou organização criminosa não era o elemento chave da convenção, não existindo, portanto, a necessidade em defini-lo. Outro grupo de países defendia que, diante da incessante mutação, eventual conceituação do crime organizado seria ineficaz em pouco tempo. Contudo, outros membros reafirmaram a necessidade de se conceituar a expressão crime organizado, pois eventual ausência de tal conceito poderia demonstrar um dito descaso da própria ONU junto à comunidade internacional, eis que vários Estados já estavam a tentar, não sem problemas, definir o conceito de crime organizado.

Diante deste impasse, os representantes que se faziam presentes na Convenção anuíram em identificar as características ínsitas ao crime organizado como forma de melhor conceituá-lo. Os elementos apontados, incluídos em algumas formas de organização, seriam: "a continuidade; o uso da intimidação e violência; a sua estrutura hierárquica, com divisão de trabalho; o objetivo visando o lucro; e por fim, a sua influência na sociedade, na mídia e nas estruturas políticas"75.

O conceito de crime organizado utilizado nos tribunais pátrios tem se pautado na Convenção de Palermo, conforme orienta o Superior Tribunal de Justiça em um de seus julgados cuja ementa abaixo se transcreve.

ORGANIZAÇÃO CRIMINOSA. DESCAMINHO. LAVAGEM. DINHEIRO.

Trata-se de paciente denunciada em decorrência de operação policial a qual investigava as atividades de sociedades empresárias pertencentes 
ao mesmo grupo empresarial, como incursa nos arts. 288 e 334 do CP c/c art. $1^{\circ}$, V e VII, da Lei n. 9.613/1998, em continuidade delitiva. Na impetração, busca-se o trancamento parcial da ação penal quanto à acusação de lavagem de dinheiro (art. $1^{\text {}}$, VII, da Lei n. 9.613/1998) e em relação à acusação por formação de quadrilha (art. 288 do CP). Alega haver inépcia da peça vestibular no que diz respeito ao crime previsto no art. 288 do $\mathrm{CP}$, sustentando que não existe conceito legal da expressão "organização criminosa". Para o Min. Relator, o trancamento da ação penal em habeas corpus é medida excepcional e a tese da impetração não merece prosperar. Explica que a expressão “organização criminosa" ficou estabelecida no ordenamento jurídico brasileiro com o Dec. n. 5.015/2004, o qual promulgou a Convenção das Nações Unidas contra o Crime Organizado Transnacional (Convenção de Palermo, que, no art. 2, a, definiu tal conceito), aprovado pelo Dec. Legislativo n. 231/2003. Segundo o Min. Relator, a definição jurídica de organização criminosa não se submete ao princípio da taxatividade como entende a impetração, pois o núcleo do tipo penal previsto na norma é "ocultar ou dissimular a natureza, origem, localização, disposição, movimentação ou propriedade de bens, direitos ou valores provenientes, direta ou indiretamente, de crime", sendo a expressão "organização criminosa" um complemento normativo do tipo, tratando-se, no caso, de uma norma penal em branco heteróloga ou em sentido estrito, que independe de complementação por meio de lei formal. Assevera que entender o contrário, de acordo com a tese defendida pelos impetrantes, seria não admitir a existência de normas penais em branco em nosso ordenamento jurídico, situação que implicaria o completo esvaziamento de inúmeros tipos penais. Também destaca que a Recomendação n. 3/2006 do Conselho Nacional de Justiça (CNJ) propõe a adoção do conceito de "crime organizado" estabelecido na Convenção de Palermo, bem como a jurisprudência do STF e do STJ não diverge desse entendimento. Por fim, ressalta que não procedem as alegações de inépcia da inicial, pois a denúncia aponta fatos que, em tese, configuram o crime de formação de quadrilha para prática de crimes de lavagem de dinheiro e contra a Administração Pública, bem como que somente o detalhamento das provas na instrução criminal esclarecerá se houve e qual foi a participação da paciente nos delitos imputados pelo Parquet. Diante do exposto, a Turma denegou a ordem. Precedentes citados do STF: RHC 102.046-SP, DJe 10/11/2010; HC 100.637-BA, DJe 24/6/2010; HC 91.516-PI, DJe 4/12/2008; do STJ: APn 460-RO, DJ 25/6/2007; HC 77.771-SP, DJe 22/9/2009; HC 63.716-SP, DJ 17/12/2007; HC 89.696SP, DJe 23/8/2010; HC 89.472-PR, DJe 3/8/2009, e HC 102.292-SP, DJe $22 / 9 / 2008 .^{76}$ 


\section{POLÍTICA CRIMINAL DA EMERGÊNCIA E CRÍTICAS À TIPIFICAÇÃO PENAL DA ORGANIZAÇÃO CRIMINOSA}

Nas sociedades globalizadas surgiram incertezas e preocupações que, não raras vezes, criam o ambiente adequado para que a ignorância de parte da população e a demagogia do legislador reclamem pela intervenção emergencial do Direito Penal para solucionar os "novos problemas de segurança pública".

Essa emergência penal ${ }^{77}$ não possui limites temporais e geográficos, fugindo "dos padrões tradicionais de tratamento pelo sistema repressivo, constituindo um subsistema de derrogação dos cânones culturais empregados na normalidade"

Num certo sentido a criminologia contemporânea dá guarida a esse subsistema, colocando-o na escala mais elevada de gravidade criminosa a justificar a adoção de mecanismos excepcionais a combatê-la, embora sempre defenda o modelo de "estado democrático e de direito" como limite máximo da atividade legiferante nessa seara. Basicamente, no caso pátrio, os graus de criminalidade são definidos na própria Constituição de 1998, onde se encontram as "infrações penais de menor potencial ofensivo" e os "crimes hediondos", restando entre eles a criminalidade "normal". No entanto, a dissonância de valores entre eles impede a consolidação da cultura democrática do texto maior na prática jurídica a justificar a indagação sobre quando o due process of law não é embaraço ao sistema repressivo, na medida em que suas regras, no direito brasileiro, são derrogadas em ambas extremidades da repressão penal e, a muito custo, observadas no quotidiano dessa mesma Justiça. ${ }^{78}$

A presença do subsistema da emergência se revela na tomada de medidas extraordinárias que mitigam garantias fundamentais do cidadão, em prol de uma resposta imediata que combata a crescente criminalidade. Estas medidas de exceção são, de fato, responsáveis pelo retrocesso dos ordenamentos jurídicos que, mesmo numa roupagem moderna, se voltam aos "velhos esquemas substanciais próprios da tradição penal pré-moderna, bem como na recepção pela atividade judiciária de técnicas inquisitivas e de métodos de intervenção que são típicos da atividade de polícia"79. Ademais, a emergência penal se legi- 
tima a partir de uma argumentação política do Estado, desrespeitando, por sua vez, todas as garantias políticas e jurídicas dos cidadãos, conforme defendido também por Ferrajoli, quando afirma que

A fonte de legitimação da legislação de emergência vem da assunção, pelo Estado, desta exceção ou emergência (antiterrorista, antimafiosa, etc.) como justificação política da ruptura das regras do jogo que no Estado de direito disciplinam o direito penal. Esta concessão da emergência outra coisa não é que a idéia do primado da razão de Estado sobre a razão jurídica como critério informador do direito e do processo penal. Ela equivale a um princípio normativo de legitimação da intervenção punitiva: não mais jurídica, mas imediatamente política; não mais à lei enquanto sistema de vínculos e de garantias, mas à esta supraordenada. A salvaguarda, ou apenas o Estado, é a norma principal do "direito de emergência". ${ }^{80}$

Essa legitimação política da emergência significa duas coisas: (i) a presença de uma legislação de exceção em relação à Constituição, provocando, portanto, quebra das regras do jogo; (ii) "a jurisdição de exceção por sua vez degradada em relação à mesma legalidade alterada" ${ }^{81}$. Assim, em relação a esta segunda consequência, tem-se que, no estado emergencial, o processo é mitigado, exaurindo suas garantias em prol do efetivo combate à criminalidade.

A nova emergência pretende justificar exigências internacionais de adoção de legislação penal e processual penal autoritária em todos os países do mundo. A necessidade de defender-se, por certo não mais dos atos concretos de homicídio em massa e indiscriminados, mas sim do nebuloso terrorismo, legitima não apenas as guerras preventivas de intervenção unilateral como também legislações autoritárias com poderes excepcionais. ${ }^{82}$

Nesse sentido, pode-se afirmar que o crime organizado é uma das fontes de preocupação na atualidade. Contudo, o sentimento de insegurança gerado pelas organizações criminosas, muitas vezes alimentado por uma mídia especulativa, cria o cenário ideal para que o oportunismo legislativo se encarregue de buscar soluções que lhe tragam retorno eleitoral. O ganho político de medidas legislativas é enorme, uma vez que qualquer proposta que busque resolver um problema 
é atraente, ainda que com isso se fira uma garantia constitucional ${ }^{83}$. Logo, conclui-se pelo uso político do Direito Penal para finalidades eleitoreiras, de forma que os objetivos populistas se sobressaem aos direitos e garantias fundamentais.

Todo observador realista e a maioria dos governos sabiam que não se diminuía nem mesmo se controlava o crime executando-se criminosos ou pela dissuasão de longas sentenças penais, mas todo político conhecia a força enorme e emocionante carregada, racional ou não, da exigência em massa dos cidadãos comuns para que se punisse o anti-social. ${ }^{84}$

Como se isso não bastasse, atualmente, ganha corpo um movimento ideológico pelo qual o Direito Penal clássico seria insuficiente para debelar o inimigo, sendo necessário, portanto, expandir o sistema criminal através do incremento de penas, maior rigor na execução criminal, criação de novos tipos penais, abertura de exceções de garantias constitucionais, dentre outros. Cancio Meliá percebeu tal questão, associando-a ao modelo de sistema no qual uma legislação "puramente simbólica e impulsos punitivistas de diversa proveniência se potencializam mutuamente, cada vez com maior intensidade, resultando na expansão quantitativa e qualitativa do Direito Penal" (trad. livre) ${ }^{85}$.

Nesse sentido, uma das principais propostas para o combate e prevenção ao crime organizado tem sido a tipificação penal das organizações como um delito autônomo ${ }^{86}$. Esta tendência político-criminal, além de embasar-se em um Direito Penal simbólico, encontra diversos obstáculos dogmáticos e constitucionais, conforme se passa a analisar.

\section{A DEFINIÇÃO DE ORGANIZAÇÃO CRIMINOSA E O PRINCÍPIO DA LEGALIDADE}

No Direito Penal, a definição de determinado fenômeno tem sua importância realçada na limitação do poder punitivo estatal, acabando por repercutir no princípio da legalidade. Segundo Santiago Mir Puig87, o princípio da legalidade refletiu uma das principais conquistas da Revolução Francesa, tendo sua origem formal na famosa expressão latina cunhada por Feuerbach: nullum crimen, nulla poena sine lege. Atualmente, praticamente todas as Constituições modernas e as Declarações de 
Direitos consagraram tal princípio ${ }^{88}$, inclusive o Brasil, que o amparou no artigo $1^{\circ}$ do Código Penal e no artigo $5^{\circ}$, XXXIX, da CRFB/1988.

Dentre os desdobramentos do referido princípio, encontra-se o princípio da taxatividade que proíbe o estabelecimento de incriminações vagas e imprecisas, determinando ao legislador o emprego de “técnicas específicas de qualificação penal idônea (taxatividade) a garantir com a taxatividade dos pressupostos da pena, a decidibilidade da verdade de seus enunciados" 89

O uso genérico da expressão "organizações criminosas", tal como é feito no Brasil, afronta o princípio da taxatividade e, portanto, o próprio princípio da legalidade previsto na CRFB/1988. É necessário que o legislador expresse o significado normativo do "crime organizado", especificando, formalmente, suas características, sob pena de inconstitucionalidade. Ressalte-se que a Lei n. 9.034/95 não definiu as organizações criminosas, apenas as equiparou ${ }^{90}$ às quadrilhas, bandos ou associações criminosas em seu artigo $1^{\circ}$, o que é um grave equívoco, afinal, o que não é semelhante não pode ser equiparado.

Além de não definir o que sejam as organizações criminosas, o legislador vem, constantemente, utilizando a referida expressão para dar tratamento a outras situações na legislação esparsa, tal como ocorre no artigo $33, \S 4^{\circ}$, da Lei $11.343 / 2006$ e artigo 52 , $\S 2^{\circ}$, da Lei $7.210 / 84$, em clara violação ao princípio da legalidade. Trata-se do uso de tipos legais abertos para dar tratamento jurídico a uma situação cuja ideia não se sabe o que é. Assim, "em face das dificuldades para tornar concreto legislativamente o conceito de 'organização criminosa', opta-se por definições abertas, com traços próximos ao do crime habitual ou da formação de quadrilha" ${ }^{11}$.

Não se pode submeter aceitar a presença de conceitos vagos e indeterminados e incorrer em autoritarismos jurisdicionais. Deve-se ter em mente a advertência de que a "arbitrariedade pode ser produzida em uma mesma determinação legal" ${ }^{\prime 2}$, daí a necessidade do princípio da taxatividade como uma garantia constitucional. Nesse sentido, Greco ${ }^{93}$ alerta que, nos países totalitários, é muito comum o uso do Direito Penal para dar ares de legalidade a atos ilegais. Aliás, nada mais conveniente a um regime antidemocrático do que se valer da expressão "organização 
criminosa" de forma generalizada para que o Estado imponha seu aparato criminal. Ressalte-se que, ainda que não se opte por tipificar penalmente as organizações criminosas, o princípio da legalidade não deixa de ser menos importante na sua definição legal, uma vez que o uso da expressão organização criminosa pode acarretar graves consequências de ordem investigatória, processual e de execução penal, sobretudo na limitação ou privação de direitos, liberdade e garantias ${ }^{94}$.

Sob o paradigma do Estado Democrático de Direito toda discussão acerca do crime organizado passa pela análise dos princípios constitucionais que norteiam o sistema jurídico, e, portanto, necessariamente pela definição legal da organização criminosa.

\section{A TIPIFICAÇÃO PENAL DAS ORGANIZAÇÕES CRIMI- NOSAS E SEU BEM JURÍDICO}

Uma das maiores dificuldades para a tipificação penal do crime organizado consiste em encontrar o seu bem jurídico ${ }^{95}$. Nisso talvez tenham residido as limitações doutrinárias e legais para encontrar uma definição típica de organizações criminosas.

Sabe-se que o bem jurídico exerce diversas funções no Direito Penal moderno, sendo a base da racionalidade do seu sistema ${ }^{96}$. Trata-se de verdadeira limitação ao poder punitivo estatal que só é legitimado a criar delitos que protejam bens jurídicos de relevância constitucional.

No caso da tipificação penal das organizações criminosas, Can$\mathrm{cio}^{97}$ afirma que a doutrina inclina-se para identificar um bem jurídico coletivo que compreenderia a "segurança pública, a segurança pública interior ou a ordem estatal". Na Itália, país no qual se incrimina a associação do tipo mafioso (art. 416-bis do Código Penal italiano), o objeto da tutela penal compreende uma vasta série de bens jurídicos, tais como a ordem pública, a segurança coletiva, a boa ordem exterior, liberdade dos associados, a liberdade moral dos cidadãos não pertencentes ao grupo e à ordem democrática ${ }^{98}$. Fiandaca e Musco, citados por Selim ${ }^{99}$, afirmam que a associação de tipo mafioso tem tendência pluriofensiva, sendo ela "capaz de ameaçar, além da ordem democrática e da ordem pública, também as condições que asseguram a liberdade de mercado e de iniciativa". 
Essa imensa gama de bens jurídicos indica algo que vai além da pluriofensividade do tipo penal, ou seja, cuida-se do uso equivocado do conceito de bem jurídico como meio legitimador da persecução criminal. Por esse raciocínio, estabelece-se uma ampliação exagerada ou mesmo distorcida do bem jurídico protegido pela norma, o que propicia ao legislador um meio de promover a criminalização, ilimitadamente ${ }^{100}$.

Percebe-se, assim, não só a deficiência conceitual das organizações criminosas, mas também o caráter lacônico, variado e impreciso do seu bem jurídico, o que gera insegurança em qualquer tentativa de tipificar penalmente o crime organizado.

\section{CRIME ORGANIZADO E PRINCÍPIO DA CULPABILIDADE}

Atualmente, diversas disposições legais que tratam do crime organizado têm um forte viés de reprovação ao autor do fato (Direito Penal do autor) e não do fato praticado pelo autor (Direito Penal do fato). Trata-se de uma responsabilidade penal atribuída pela simples condução de vida do agente, sem importar por aquilo o que ele fez. Nesse contexto, um dos exemplos mais notórios é o artigo 52 da Lei de Execução Penal, Lei n. 7.210/84, com a redação dada pela Lei n. 10.792/2003, que cuidou do regime disciplinar diferenciado.

O regime disciplinar diferenciado é uma espécie de sanção disciplinar consistente no recolhimento do preso provisório ou condenado à cela individual com limitação de visitas e de banho de sol pelo prazo máximo de 360 dias, sem prejuízo da repetição da sanção por nova falta grave da mesma espécie até o limite de um sexto da pena aplicada. Conforme o $\$ 2^{\circ}$ do artigo 52 da LEP, sujeita-se ao mencionado regime disciplinar "o preso provisório ou o condenado sob o qual recaiam fundadas suspeitas de envolvimento ou participação, a qualquer título, em organizações criminosas, quadrilha ou bando". A lei, entretanto, não definiu o que seriam as referidas organizações criminosas. Segundo Renato Marcão (2008), isso poderá gerar graves riscos e abusos constantes, uma vez que:

Por certo, e infelizmente, não faltarão juízes e promotores de Justiça; aqueles que por sorte constituem exceção, porém perigosa parcela, que 
logo se desarvorarão a enxergar onde não existe nem nunca existiu; na escuridão de suas visões limitadas, medíocres, e não raras vezes criminosas, diante de todos os bem intencionados e em relação a determinados infelizes, fundadas suspeitas de envolvimento ou participação, a qualquer título, em organizações criminosas, quadrilha ou bando. Tais autoridades por certo 'brilharão os olhos' ofuscados pela particular inteligência e devoção à Justiça que nem mesmo elas acreditam ter, diante da possibilidade de mais um arbítrio gerador de profundo drama humano, e com razoável paz de espírito irão sustentar tratar-se de 'interpretação da lei', 'subsunção do fato' etc. ${ }^{101}$

Se isso não bastasse, verifica-se que, em tal disposição legal, o fato praticado torna-se secundário em relação à forma de condução de vida do autor. Primeiro porque "qualquer pessoa que se inclua nos delitos previstos de organização criminosa já estaria incluída no regime de exclusão". Segundo porquanto "a lei somente faz referência à suspeita de pertencer a uma organização, isto é, não se faz necessário qualquer prova nesse sentido" 102 .

Evidentemente que, ao considerar o modo de vida de alguém para lhe aplicar regime mais severo na execução penal, o legislador se afastou do princípio da culpabilidade, o que foi de todo inconveniente e inadequado.

\section{CRIMES DE PERIGO ABSTRATO: ANTECIPAÇÃO DA TUTELA PENAL}

A periculosidade do crime organizado e os graves danos sociais causados por ele fez com que se buscassem medidas eficazes no âmbito do direito penal para combatê-lo. Propôs-se, então, recorrer ao crime de perigo abstrato para a resolução dos problemas provocados pela nova criminalidade, "confiando nele como equipamento indispensável para assegurar maior e real funcionalidade e eficiência ao próprio direito penal, no contexto de conflitos intangíveis pelos critérios de matiz individual" 103 .

Os crimes de perigo abstrato ou presumido são delitos nos quais o tipo penal incriminador, para fins de caracterização do perigo, satisfaz-se com a conduta do agente. Não há necessidade que se comprove 
a ameaça ou lesão ao bem jurídico, pois há uma presunção iure et iure de que a simples conduta do autor já o colocou em risco. Tais crimes violam o princípio da lesividade, na medida em que a potencialidade do dano proveniente da conduta não é verificada ${ }^{104}$. Da mesma forma, tais crimes afetam o princípio da não-culpabilidade, uma vez que o comportamento do agente é presumidamente danoso.

Não obstante as várias críticas dirigidas aos crimes de perigo abstrato, o Direito Penal foi encontrar nestes tipos de delito uma das soluções para o tratamento jurídico dado às organizações criminosas. No caso específico do crime organizado, os crimes de perigo abstrato antecipam para o estágio preparatório a punição de um delito futuro.

Analisando a função político-criminal dos delitos de associação, $\mathrm{Paz}^{105}$ revela que estes crimes cumprem uma função exclusivamente preventiva, já que punem condutas preparatórias à consecução de um futuro delito ou mesmo atitudes prévias à preparação de um determinado crime. Para a referida autora ${ }^{106}$, a incriminação das associações de pessoas justifica-se por dois motivos principais: a) cumpre uma função facilitadora no conjunto de provas dos crimes praticados pela associação; b) permite a condenação por um delito autônomo àqueles membros da organização cuja participação em delitos concretos seja impossível comprovar.

Ora, não se pode admitir, no Direito Penal de um Estado Democrático, que crimes sejam criados com base em critérios "facilitadores de provas". Afinal, o único compromisso de um sistema que se pauta por tais critérios é o de aumentar as estatísticas de condenação criminal. Além de violar uma vasta gama de princípios constitucionais, esta técnica de incriminação ofende postulados clássicos de um sistema jurídico composto por direitos fundamentais, sendo uma clara manifestação do Direito Penal do Inimigo.

Na verdade, mesmo no crime de quadrilha ou bando, o centro da responsabilidade criminal está mais ligado aos futuros delitos que se praticarão do que à própria associação criminosa. Antecipar para um estágio preparatório a punição de um delito que ainda pode ocorrer só é conveniente àqueles que se arvoram no exercício da futurologia, pois "quem pune fatos futuros, já não tem razão alguma para deixar impune os pensamentos"107. 


\section{CONCLUSÃO}

A globalização é um fenômeno mundial que provocou sensíveis modificações no cenário sócio-econômico, político e cultural. Nessa nova ordem, o crime organizado emergiu como um dos grandes desafios a ser enfrentado pelos órgãos persecutórios dos Estados soberanos.

Premido por soluções enérgicas e imediatas, o Estado vem se valendo, principalmente, do Direito Penal para combater o crime organizado, havendo uma tendência à tipificação cada vez mais rígida deste novo tipo de criminalidade.

Se por um lado não se ignora os graves danos causados pelas organizações criminosas, por outro não se pode admitir que o Estado se valha de uma política criminal de fins políticos para conferir ao direito penal um valor simbólico no trato da questão, sobretudo quando isso fere direitos e garantias previstos constitucionalmente.

A tipificação penal das organizações criminosas enfrenta sérios problemas que, na perspectiva do Estado Democrático de Direito, o legislador e a doutrina ainda não souberam solucionar. Dentre os principais obstáculos a serem superados para a referida criminalização encontram-se: (i) a dificuldade em definir as organizações criminosas e a sua repercussão no princípio da legalidade; (ii) a imprecisão de seu bem jurídico; (iii) a violação ao princípio da culpabilidade; (iv) o uso recorrente do crime de perigo abstrato como antecipação da tutela penal.

Na fantástica obra de Mario Puzo (2007, p. 107), “O Poderoso Chefão", Dom Vito Corleone adverte seu filho Santino para que este "nunca deixe alguém saber o que pensa intimamente". Parece que esta lição continua sendo seguida pela doutrina e pelo legislador que ainda não conseguiram dar tratamento jurídico adequado à tipificação penal das organizações criminosas sem que isso violasse postulados fundamentais do Estado Democrático de Direito.

\section{REFERÊNCIAS}

BARATTA, Alessandro. Criminologia crítica e crítica do direito penal: introdução à sociologia do direito penal. Tradução de Juarez Cirino dos Santos. 3. ed. Rio de Janeiro: Renavan, 2002. 
BARBOSA, Alexandre de Freitas. O mundo globalizado: política, sociedade e economia. São Paulo: Contexto, 2008.

BAUMAN, Zygmunt. Globalização: as consequências humanas. Tradução de Marcus Penchel. Rio de Janeiro: Jorge Zahar Editor, 1999.

BOFF, Leonardo. Os desafios atuais no compromisso pelos direitos humanos. In: Durval Ângelo Andrade (Org). O direito de ter direitos: a mais valia dos desvalidos. Belo Horizonte: Bigráfica, 2009.

BRASIL. Ministério da Fazenda. Conselho de Controle de Atividades Financeiras. 100 Casos de Lavagem de Dinheiro: Grupo de Egmont FIUs em ação. Brasília: 2001. Disponível em: <https://www.coaf.fazenda.gov.br/downloads/100_Casos.pdf> Acessado em: 01mar. 2010.

BRASIL. Ministério da Fazenda. Conselho de Controle de Atividades Financeiras. Lavagem de dinheiro: o que é? Como e onde acontece? Brasília: [200-] Disponível em: <https:/ / www.coaf.fazenda.gov.br/conteudo/publicacoes/downloads/cartilha.pdf> Acessado em: 01 mar. 2010.

CALLEGARI, André Luís. Importância e efeito da delinqüência econômica. Boletim IBCCRIM, São Paulo, n. 101, p. 10-11, abr. 2001.

CALLEGARI, André Luís; MELIÁ, Manuel Cancio; BARBOSA, Paula Andrea Ramírez. Crime Organizado: Tipicidade - Política Criminal - Investigação e Processo: Brasil, Espanha e Colômbia. Porto Alegre: Livraria do Advogado, 2008.

CALLEGARI, André Luis; WERMUTH, Maiquel Ângelo Dezordi. Crime Organizado: conceito e possibilidade de tipificação diante do contexto de expansão do direito penal. Revista Brasileira de Ciências Criminais. São Paulo, 2009, vol. 17, n. 79, p. 7-40.

CHOUKR, Fauzi Hassan. Bases para compreensão e crítica do direito emergencial. 2005. Disponível em: < http:/ / www.mundojuridico.adv. br/sis_artigos/artigos.asp?codigo=673 >. Acesso em: 01mar.2010.

DIAS, Jorge de Figueiredo. A criminalidade organizada: do fenômeno ao conceito jurídico penal. Revista Brasileira de Ciências Criminais. São Paulo, 2008, vol. 16, n. 71, p. 11-30. 
FERNANDES, Antonio Scarance. O equilíbrio entre a eficiência e o garantismo e o crime organizado. Revista Brasileira de Ciências Criminais, São Paulo, v. 16, n. 70, p. 229-268, 2008.

FERRAJOLI, Luigi. Direito e razão: a teoria do garantismo penal. 3. ed. São Paulo: Revista do Tribunais, 2010.

FERRO, Ana Luiza Almeida. Crime Organizado e Organizações Criminosas Mundiais. Curitiba: Juruá Editora, 2009.

GOMES, Abel Fernandes; PRADO, Geraldo; DOUGLAS, William. Crime Organizado e suas conexões com o poder público. Comentários à Lei $n^{0}$ 9.034/95. Considerações críticas. Rio de Janeiro: Impetus, 2000.

GRECO, Rogério. Curso de direito penal: parte especial. 6. ed. Niterói: Impetus, 2009. v. 2.

. GRECO, Rogério. Direito penal do equilíbrio: uma visão minimalista do direito penal. 3. ed. Niterói: Impetus, 2008.

HASSEMER, Winfried. Límites del Estado de Derecho para el combate contra la criminalidad organizada. Revista de Estudos Criminais, v. 5, n. 19, p. 11-16, 2003.

HOBSBAWN, Eric. Era dos extremos: o breve séc. XX: 1914-1991. Tradução de Marcos Santarrita. 2a . ed. São Paulo: Companhia das Letras, 1995.

LIPOVETSKY, Gilles. Le bonheur paradoxal - Essai sur la société d'hyperconsommation. Paris: Gallimard, 2006.

LOPES, Maurício Antonio Ribeiro. Princípio da Legalidade Penal. São Paulo: Editora Revista dos Tribunais, 1994.

MACHADO, F. D. A.. A Globalização dos Direitos Humanos (apresentação). Revista do Instituto de Hermenêutica Jurídica, Belo Horizonte, v. 1, n. 7, p. 7-9, 2009 b.

MACHADO, F.D.A. Direito e Política na Emergência Penal: uma análise crítica à flexibilização de direitos fundamentais no discurso do Di- 
reito Penal do inimigo. In: Revista de Estudos Criminais. Porto Alegre, ano 9, n. ${ }^{\circ} 34$, p. 69-92, jul./set. 2009a.

MAGALHÃES, Mário. O Narcotráfico. São Paulo: Publifolha, 2000.

MARCÃO, Renato. Curso de execução penal. 6. ed. São Paulo: Editora Saraiva, 2008.

MARTÍN, Luis Gracia. O horizonte do finalismo e o Direito penal do inimigo. Trad. Luiz Regis Prado; Érika Mendes de Carvalho. São Paulo: Editora Revista dos Tribunais, 2007.

MONTOYA, Mario Daniel. Máfia e Crime Organizado. Rio de Janeiro: Lumen Juris, 2007.

PAZ, Isabel Sánches García de. Función político-criminal del delito de asociación para delinquir:desde el Derecho Penal político hasta la lucha contra el crimen organizado. Disponível em: <https:/ / www.cienciaspenales.net/descargas/idp_docs/doctrinas>. Acessado em 08 mar. 2010.

PELLEGRINI, Angiolo; COSTA JÚNIOR, Paulo José. Criminalidade Organizada. $2^{\text {a }}$ ed. São Paulo: Editora Atlas, 2008.

PIERANGELI, José Henrique. Manual de direito penal brasileiro. 2. ed. São Paulo: Revista dos Tribunais, 2007. v. 2.

PIOVESAN, Cláudia. Declaração Universal de Direitos Humanos: desafios e perspectivas. Revista do Instituto de Hermenêutica Jurídica, Belo Horizonte, v. 1, n. 7, p. 11-37, 2009.

PITOMBO, Antônio Sérgio Altieri de Moraes. Organização Criminosa: Nova perspectiva do tipo legal. São Paulo: Editora Revista dos Tribunais, 2009.

PRADO, Luiz Regis. Curso de direito penal brasileiro. 8. Ed. São Paulo: Editora Revista dos Tribunais, 2008. v. 1.

PUIG, Santiago Mir. Derecho penal: parte general. 8. ed. Buenos Aires: Julio César Faira Editor, 2009. 
PUZO, Mario. O Poderoso Chefão. Trad. de Carlos Nayfeld. Rio de Janeiro: BestBolso, 2007.

SALES, Sheila Jorge Selim de. Escritos de direito penal. 2. ed. Belo Horizonte: Editora Del Rey, 2005.

SALLA, Fernando. Considerações sociológicas sobre o crime organizado no Brasil. Revista Brasileira de Ciências Criminais, São Paulo, v. 16, n. 71, p. 364-390. 2008.

SANDRONI, Gabriela Araújo. A Convenção de Palermo e o crime organizado transnacional. Disponível em: <http://www.ceeri.org.ar/ trabajosestudiantes/sandroni_CrimenOrganizadoInternacional.pdf $>$. Acesso em: 08 de mar. 2010.

SANTOS, Juarez Cirino dos. Crime Organizado. Revista Brasileira de Ciências Criminais, São Paulo, v. 11, n. 42, p. 214-224, 2003.

SCHMITT, Carl. O conceito do político e a teoria do partisan. Trad. Geraldo de Carvalho. Belo Horizonte: Del Rey, 2009.

SILVA SANCHEZ, José Maria. A expansão do Direito Penal. Trad. Luiz Otávio Rocha. São Paulo: Editora Revista dos Tribunais, 2002.

SILVA, Ivan Luiz da. Crime organizado: aspectos jurídicos e criminológicos (Lei no 9.034/95). Belo Horizonte: Nova Alvorada Edições, 1998.

STERLING, Claire. A máfia globalizada: A nova ordem mundial do crime organizado. Trad. Alda Porto. Rio de Janeiro: Renavan, 1997.

STRECK, Lenio Luiz. Hermenêutica Jurídica e(m) crise: uma exploração hermenêutica da construção do direito. 2. ed. Porto Alegre: Livraria do Advogado, 2000.

SZNICK, Valdir. Crime Organizado: comentários. São Paulo: Livraria e Editora Universitária de Direito, 1997.

VAGGIONE, Luiz Fernando; SILVEIRA, Rodrigo Mansour Magalhães da. O crime organizado na Itália e as medidas para o seu combate. In: 


\title{
Antonio Scarance Fernandes; José Raul Gavião de Almeida; Maurício Zanoide de Moraes (Coord). Crime Organizado: aspectos processuais. São Paulo: Editora Revista dos Tribunais, 2009, p. 232-250.
}

\section{ZAFARONI, Eugenio Raúl. O inimigo no direito penal. Trad. Sérgio Lamarão. Rio de Janeiro: Revan, 2007.}

\author{
ZAFFARONI, Eugenio Raul; ALAGIA, Alejandro; SLOKAR, Alejan- \\ dro. Derecho penal: parte general. 2. ed. Buenos Aires: Ediar, 2008.
}

\section{NOTAS}

1 MACHADO, F.D.A. Direito e Política na Emergência Penal: uma análise crítica à flexibilização de direitos fundamentais no discurso do Direito Penal do inimigo. In: Revista de Estudos Criminais. Porto Alegre, ano 9, n. ${ }^{\circ}$ 34, p. 69-92, jul./set. 2009a,p.70.

2 SILVA SANCHEZ, José Maria. A expansão do Direito Penal. Trad. Luiz Otávio Rocha. São Paulo: Editora Revista dos Tribunais, 2002.

3 PIERANGELI, José Henrique. Manuel de Direito Penal Brasileiro. vol. 2. 2ª . ed. São Paulo: Revista dos Tribunais, 2007, p. 678.

4 MARTÍN, Luis Gracia. O horizonte do finalismo e o Direito penal do inimigo. Trad. Luiz Regis Prado; Érika Mendes de Carvalho. São Paulo: Editora Revista dos Tribunais, 2007, p. 129.

5 CAlleGARI, André Luís; MELIÁ, Manuel Cancio; BARBOSA, Paula Andrea Ramírez. Crime Organizado: Tipicidade - Política Criminal - Investigação e Processo: Brasil, Espanha e Colômbia. Porto Alegre: Livraria do Advogado, 2008, p. 18.

6 MACHADO, F. D. A.. A Globalização dos Direitos Humanos (apresentação). In: Revista do Instituto de Hermenêutica Jurídica. Belo Horizonte: Instituto de Hermenêutica Jurídica, v. 1, n. 7, p. 07-09, 2009b, p. 7-8.

7 BOFF, Leonardo. Os desafios atuais no compromisso pelos direitos humanos. In: Durval Ângelo Andrade (Org). O direito de ter direitos: a mais valia dos desvalidos. Belo Horizonte: Bigráfica, 2009, p. 182.

8 BARBOSA, Alexandre de Freitas. O mundo globalizado: política, sociedade e economia. São Paulo: Contexto, 2008, p. 12-13.

9 (BAUMAN, 1999, p. 77)

10 PIOVESAN, Cláudia. Declaração Universal de Direitos Humanos: desafios e perspectivas. In: Revista do Instituto de Hermenêutica Jurídica. Belo Horizonte: Instituto de Hermenêutica Jurídica, v. 1, n. 7, p. 11-37, 2009, p. 28.

11 (BAUMAN, 1999, p. 74)

12 (BAUMAN, 1999, p. 67)

13 LIPOVETSKY, Gilles. Le bonheur paradoxal - Essai sur la société d'hyperconsommation. Paris: Gallimard, 2006, p. 327.

14 CALLEGARI, Op. Cit. p. 14.

15 "A força e a violência são meios que não interessam, a princípio, pois acabam por atrair indesejável atenção da imprensa, de parte das autoridades e da própria população, que sempre exerce influência nas iniciativas dos políticos. Se ambas, de alguma forma, possuem inegável aptidão para intimidar, por outro lado, podem gerar repulsa, revolta imponderável e conseqüente ação inesperada e contrária. Assim sendo, é muito mais adequado que as organizações criminosas adotem medidas menos drásticas, optando por inferências mais sutis e discretas, em prol da manutenção de sua operacionalidade." (GOMES, 2000, p. 8)

16 MAGALHÃES, Mário. O Narcotráfico. São Paulo: Publifolha, 2000, p. 53. 
17 STERLING, Claire. A máfia globalizada: A nova ordem mundial do crime organizado. Trad. Alda Porto. Rio de Janeiro: Renavan, 1997, p. 16.

18 Criado pela Lei 9.613/98, o Conselho de Controle de Atividades Financeiras (COAF) é órgão ligado ao Ministério da Fazenda que, segundo o artigo 14 daquele diploma legal, tem a "finalidade de disciplinar, aplicar penas administrativas, receber, examinar e identificar as ocorrências suspeitas de atividades ilícitas previstas nesta lei, sem prejuízo da competência de outros órgãos e entidades".

19 O Grupo de Egmont é "um organismo internacional informal, criado por iniciativa da Unidade Financeira de Inteligência belga (CTIF) e norte-americana (FINCEN) para promover, em nível mundial, a troca de informações, o recebimento e o tratamento de comunicações suspeitas relacionadas à lavagem de dinheiro provenientes dos outros organismos financeiros." (BRASIL, 2001, p. 02).

20 GOMES, Abel Fernandes; PRADO, Geraldo; DOUGLAS, William. Crime Organizado e suas conexões com o poder público. Comentários à Lei $n^{\circ}$ 9.034/95. Considerações críticas. Rio de Janeiro: Impetus, 2000. p. 8.

21 Idem, p. 8.

22 Idem, p. 11.

23 A inserção do crime organizado no Poder Público pode ser caracterizada como "estruturas organizadas e integradas por funcionários públicos, incrustadas dentro do organismo estatal, seguindo uma hierarquia vertical ou horizontal de decisões e execução de ações, com a finalidade de obter vantagens, através da prática de atos administrativos ou judiciais impróprios para a situação legal e jurídica específica, cuja ilegitimidade está, exatamente, na finalidade com a qual são praticados, qual seja a de atender a outros interesses pessoais destes agentes públicos, de obtenção de riqueza ou poder." (GOMES, 2000, p. 13)

24 Raúl Cervini (1997, p. 266)

25 CALLEGARI, Op. Cit. p. 10.

26 Conforme ressalta Lenio Luiz Streck (2000, p. 35-36) “a dogmática jurídica coloca á disposição do operador um prê-à-porter significativo contendo uma resposta pronta e rápida! Mas, quando Caio (sic) e milhares de pessoas sem teto ou sem terra invadem/ocupam a propriedade de Tício (sic), ou quando Caio (sic) participa de uma 'quebradeira' de bancos, causando desfalques de bilhões de dólares (como no caso do Banco Nacional, Bamerindus, Econômico, Coroa-Brastel, etc.), os juristas só conseguem 'pensar' o problema a partir da ótica forjada no modo liberal-individualista-normativista de produção do Direito"

27 No original: "sea por las técnicas empleadas, sea por los medios de que dispone, o por los inmensos daños visibles y subterráneos que causa" (CERVINI, 1997, p. 237).

28 CALLEGARI, Op. Cit.

29 FERNANDES, Antonio Scarance. O equilíbrio entre a eficiência e o garantismo e o crime organizado. Revista Brasileira de Ciências Criminais. São Paulo, 2008, vol. 16, n. 70, p. 237.

30 Scarance (2008, p. 231)

31 Nesse sentido, pode-se destacar esta tendência do uso da transação penal e da suspensão condicional do processo. (FERNANDES, 2008, p. 231-232)

32 FERNANDES,Op. Cit. P. 232.

33 Idem, p. 232.

34 HASSEMER, Winfried. Límites del Estado de Derecho para el combate contra la criminalidad organizada. Revista de Estudos Criminais. 2003, vol. 5, n. 19, p. 11-16.

35 Necessário advertir que, embora o crime organizado e a criminalidade de massas sejam fenômenos distintos, há um ponto comum entre eles: "é quando a segunda é decorrente da primeira, que aparece como geratriz, de sorte que, a despeito de constituírem diferentes tipos de criminalidade, da organização criminosa deriva parte da criminalidade de massas" (FERRO, 2009, p. 328).

36 BARATTA, Alessandro. Criminologia Crítica e Crítica do Direito Penal: Introdução à Sociologia do Direito Penal. $3^{\text {a }}$ ed. Trad. Juarez Cirino dos Santos. Rio de Janeiro: Renavan, 2002, p. 101.

37 FERRO, Ana Luiza Almeida. Crime Organizado e Organizações Criminosas Mundiais. Curitiba: Juruá Editora, 2009, p. 331. 
38 Idem, p. 331.

39 Várias são as dificuldades para o combate ao crime de colarinho branco, dentre eles, destaca Alessandro Barata (2002, p. 102): "fatores que são ou de natureza social (o prestígio dos autores das infrações, o escasso efeito estigmatizante das sanções aplicadas, a ausência de um estereótipo que oriente as agências oficiais na perseguição das infrações, como existe, ao contrário, para as infrações típicas dos estratos mais desfavorecidos), ou de natureza jurídicoformal (a competência de comissões especiais, ao lado da competência de órgãos ordinários, para certas formas de infrações, em certas sociedades), ou, ainda, de natureza econômica (a possibilidade de recorrer a advogados de renomado prestígio, ou de exercer pressões sobre os denunciantes etc)"

40 Ana Luiza Almeida Ferro (2009, p. 333)

41 SZNICK, Valdir. Crime Organizado: comentários. São Paulo: Livraria e Editora Universitária de Direito, 1997, p. 62.

42 Idem, p. 62.

43 MONTOYA, Mario Daniel. Máfia e Crime Organizado. Rio de Janeiro: Lumen Juris, 2007, p. 99.

44 SZNICK, Op. Cit., p. 55.

45 FERRO, Op. Cit., p. 345.

46 Idem, p. 345.

47 Esse engajamento político do terrorismo se assemelha àquele dado por Carl Schmitt (2009, p. 162) ao movimento partisan.

48 VAGGIONE, Luiz Fernando; SILVEIRA, Rodrigo Mansour Magalhães da. O crime organizado na Itália e as medidas para o seu combate. In: Antonio Scarance Fernandes; José Raul Gavião de Almeida; Maurício Zanoide de Moraes (Coord). Crime Organizado: aspectos processuais. São Paulo: Editora Revista dos Tribunais, 2009, p. 235.

49 Idem, p. 233.

50 Idem, p. 233.

51 Pellegrini e Costa Júnior (2008, p. 5)

52 Atribui-se à máfia os "omicidi eccelenti" da história italiana, dentre dos quais se destacam os dos juízes Borselino e Falcone, além do "prefeito de Palermo, General Dalla Chiesa, do presidente da Região Siciliana Mattarella e do deputado La Torre" (PELLEGRINI e COSTA JÚNIOR, 2008, p. 05).

53 PELLEGRINI, Angiolo; COSTA JÚNIOR, Paulo José. Criminalidade Organizada. $2^{\mathrm{a}}$ ed. São Paulo: Editora Atlas, 2008, p. 5-6.

54 MONTOYA, Op. Cit., p. p. 1-3.

55 "Ao lado do canal bancário, amplamente experimentado, a máfia também utiliza para essa finalidade o setor parabancário ( $\mathrm{sic}$ ) da intermediação financeira por meio de operações de bolsa, gestões financeiras e aquisição de certificados de fundos comuns de investimento, italianos e estrangeiros. Igualmente as atividades de leasing e do factoring são utilizadas com o escopo de reciclagem, como a área das sociedades comerciais e do jogo de azar legalizado." (PELLEGRINI e COSTA JÚNIOR, 2008, p. 15).

56 FERRO, Op. Cit., p. 46-48.

57 SALLA, Fernando. Considerações sociológicas sobre o crime organizado no Brasil. Revista Brasileira de Ciências Criminais. São Paulo, 2008, vol. 16, n. 71, p. 367.

58 Idem, p. 367-368.

59 FERRO, Op. Cit., p. 51.

60 PITOMBO, Antônio Sérgio Altieri de Moraes. Organização Criminosa: Nova perspectiva do tipo legal. São Paulo: Editora Revista dos Tribunais, 2009.

61 Idem, p. 166.

62 Idem, p. 52.

63 Segundo a referida autora, “A organização é então uma espécie do gênero associação ou grupo. Isto nos leva ao segundo ponto: 'organização' é um termo mais preciso, dispensando a necessidade de adjetivação respeitante à natureza organizativa, consoante se verifica em relação a expressões como 'associação organizada' e 'grupo organizado'. E não ostenta o cunho extremamente vago e indeterminado de termos como 'entidade'. Nem favorece a confusão com outros 
grupos criminosos como acontece, a título de exemplificação, com o uso da expressão 'bando criminoso' para o tipo de associação sob comento. Em terceiro lugar, é um termo relativamente 'neutro', não supervalorizando uma única dimensão desta forma associativa, como a econômica, o que é bem exemplificado em expressões como 'empresa criminosa', 'multinacional criminosa' ou 'multinacional do crime organizado'".

64 DIAS, Jorge de Figueiredo. A criminalidade organizada: do fenômeno ao conceito jurídico penal. Revista Brasileira de Ciências Criminais. São Paulo, 2008, vol. 16, n. 71, p. 12.

65 HASSEMER,Op. Cit., p. 11 - trad. Livre.

66 SANTOS, Juarez Cirino dos. Crime Organizado. Revista Brasileira de Ciências Criminais. São Paulo, 2003, vol. 11, n. 42, p. 214.

67 SALES, Sheila Jorge Selim de. Escritos de Direito Penal. $2^{\mathrm{a}}$ ed. Belo Horizonte: Editora Del Rey, 2005, p. 135.

68 Fernando Salla (2008, p. 371)

69 SALLA, Op. Cit., p. 371.

70 SALES, Op. Cit., p. 136.

71 Idem, p. 155.

72 SANTOS, Op. Cit., p. 222.

73 Convenção das Nações Unidas Contra o Crime Transnacional ocorrido no ano 2000, na Itália. Aprovada em Assembléia Geral da ONU, em Nova York, em 15.11.2000. O Brasil ratificou o texto da Convenção, em 12.03.2004, colocando-o em vigor por intermédio do Decreto n ${ }^{\circ}$. 5.015.

74 "Para efeitos da presente Convenção, entende-se por:

a) "Grupo criminoso organizado" - grupo estruturado de três ou mais pessoas, existente há algum tempo e atuando concertadamente com o propósito de cometer uma ou mais infrações graves ou enunciadas na presente Convenção, com a intenção de obter, direta ou indiretamente, um benefício econômico ou outro benefício material; b) "Infração grave" - ato que constitua infração punível com uma pena de privação de liberdade, cujo máximo não seja inferior a quatro anos ou com pena superior; c) "Grupo estruturado" - grupo formado de maneira não fortuita para a prática imediata de uma infração, ainda que os seus membros não tenham funções formalmente definidas, que não haja continuidade na sua composição e que não disponha de uma estrutura elaborada; d) "Bens" - os ativos de qualquer tipo, corpóreos ou incorpóreos, móveis ou imóveis, tangíveis ou intangíveis, e os documentos ou instrumentos jurídicos que atestem a propriedade ou outros direitos sobre os referidos ativos; e) "Produto do crime" - os bens de qualquer tipo, provenientes, direta ou indiretamente, da prática de um crime; f) "Bloqueio" ou "apreensão" - a proibição temporária de transferir, converter, dispor ou movimentar bens, ou a custódia ou controle temporário de bens, por decisão de um tribunal ou de outra autoridade competente; g) "Confisco" - a privação com caráter definitivo de bens, por decisão de um tribunal ou outra autoridade competente; h) "Infração principal" - qualquer infração de que derive um produto que possa passar a constituir objeto de uma infração definida no Artigo 6 da presente Convenção; i) "Entrega vigiada" - a técnica que consiste em permitir que remessas ilícitas ou suspeitas saiam do território de um ou mais Estados, os atravessem ou neles entrem, com o conhecimento e sob o controle das suas autoridades competentes, com a finalidade de investigar infrações e identificar as pessoas envolvidas na sua prática; j) “Organização regional de integração econômica" - uma organização constituída por Estados soberanos de uma região determinada, para a qual estes Estados tenham transferido competências nas questões reguladas pela presente Convenção e que tenha sido devidamente mandatada, em conformidade com os seus procedimentos internos, para assinar, ratificar, aceitar ou aprovar a Convenção ou a ela aderir; as referências aos "Estados Partes" constantes da presente Convenção são aplicáveis a estas organizações, nos limites das suas competências."

75 SANDRONI, Gabriela Araújo. A Convenção de Palermo e o crime organizado transnacional. Disponível em: <http://www.ceeri.org.ar/trabajosestudiantes/

sandroni_CrimenOrganizadoInternacional.pdf >. Acesso em: 08 de mar. 2010.

76 (HC 138.058-RJ, Rel. Min. Haroldo Rodrigues [Desembargador convocado do TJ-CE], julgado em 22/3/2011) (grifou-se) 
77 A emergência penal se difere da emergência constitucional dos Estados democráticos. Com Choukr (2005) afirma-se que emergência constitucional caracteriza-se por: (a) estar prevista no texto das constituições modernas; (b) possui limites temporais e geográficos, além daqueles de índole material a regrar a exceção; e (c) respeita os princípios da proporcionalidade e da não discriminação. "Assim, pode-se afirmar que a exceşão aqui tratada é um estado de direito, no sentido da necessidade de sua decretação e da sua forma de atuação" (CHOUKR, Fauzi Hassan. Bases para compreensão e crítica do direito emergencial. 2005. Disponível em: < http:/ /www. mundojuridico.adv.br/sis_artigos/artigos.asp?codigo=673 >. Acesso em: 01mar.2010.)

78 Idem

79 FERRAJOLI, Luigi. Direito e razão: a teoria do garantismo penal. $3^{a}$. ed. São Paulo: Revista do Tribunais, 2010, p. 746 .

80 Idem, p. 747.

81 Idem, p. 747.

82 ZAFFARONI, Op. Cit., p. 66.

83 Segundo Zaffaroni, “Essa legislação constitui o capítulo mais triste da atualidade latino-americana e o mais deplorável de toda a história da legislação penal na região, em que políticos intimidados pela ameaça de uma publicidade negativa provocam o maior caos legal autoritário - incompreensivel e irracional - da história de nossas legislações penais desde a independência." (ZAFFARONI, Op. Cit., p. 79 - grifos do autor).

84 HOBSBAWN, Eric. Era dos extremos: o breve séc. XX: 1914-1991. Tradução de Marcos Santarrita. $2^{\text {a }}$. ed. São Paulo: Companhia das Letras, 1995, p. 335.

85 No original: "puramente simbólica e impulsos punitivistas de diversa proveniência se potencian mutuamente cada vez com mayor intensidad, desembocando em uma expansión cuantitativa e cualitativa del Derecho penal" (CANCIO MELIA, 2008, p. 26).

86 Segundo Sheila Jorge Selim de Sales (2005, p. 226-232), a tipificação penal das organizações criminosas pode ser encontrada nos Códigos Penais italiano (arts. 416-bis), alemão (§ 129, 129a, 129b), espanhol (arts. 515-521), russo (art. 210) e austríaco (\$ 278-a). Além disso, Montoya (2007, p. 197-227) cita outros países que deram tratamento jurídico ao crime organizado, tais como os Estados Unidos, Japão, França, Bélgica e Argentina.

87 PUIG, Santiago Mir. Derecho Penal: Parte General. $8^{a}$ edição. Buenos Aires: Julio César Faira Editor, 2009, p. 105.

88 LOPES, Maurício Antonio Ribeiro. Princípio da Legalidade Penal. São Paulo: Editora Revista dos Tribunais, 1994, p. 17.

89 FERRAJOLI, Op. Cit., p. 93.

90 Nesse sentido, cabe ressaltar que "quadrilha ou bando e crime organizado apresentariam mais diferenças do que semelhanças, sendo inaceitável a transposição do art. 288 do CP para tipificar a estrutura complexa e perene da organização criminosa. $O$ grupo de pessoas, unidas de forma rudimentar, apto a tipificar a quadrilha não se coadunaria com o modelo empresarial da organização criminosa. Entre as figuras delitivas, haveria proximidade, tão-só, por configurarem espécies de associação criminosa." (PITOMBO, 2009, p. 111/112)

91 CALLEGARI, Op. Cit., p. 25.

92 No original: "arbitrariedad puede producirse en la misma determinación legal" (ZAFFARONI et al, 2002, p. 117)

93 GRECO, Rogério. Curso de Direito Penal: Parte Especial. Vol. II. $6^{\text {a }}$ Ed. Niterói, RJ: Impetus, 2009, p. 132.

94 DIAS, Op. Cit., p. 13.

95 Bem jurídico, conforme Assis Toledo (2007, p. 16), "são valores ético-sociais que o direito seleciona, com o objetivo de assegurar a paz social, e coloca sob sua proteção para que não sejam expostos a perigo de ataque ou a lesões efetivas".

96 SALES, Op. Cit., p. 127.

97 No original: "'seguridad pública', la 'seguridad pública interior' o de la 'seguridad pública y el orden estatal'" (CANCIO MELIA, 2008, p. 37).

98 SALES, Op. Cit., p. 181.

99 Fiandaca e Musco, citados por Selim (2005, p. 182) 
100 Acentuando o caráter lacônico da expressão paz pública, Pitombo (2009, p. 169) diz que tal bem jurídico ora se assenta como fim último do convívio social, ora se limita à tranqüilidade do público, o que traz indefinição ao seu conceito, já que "a proteção jurídica de valores depende de objeto certo, sob pena de se aceitarem justificativas autoritárias, representadas por expressões de efeito, todavia, carentes de fundamentação".

101 MARCÃO, Renato. Curso de Execução Penal. $6^{a}$ ed. rev. atual. São Paulo: Editora Saraiva, 2008, p. 41.

102 CALLEGARI, Op. Cit., p. 21.

103 PRADO, Luiz Regis. Curso de Direito Penal Brasileiro. Vol. 1. $8^{\text {a }}$ ed. rev., atual. e ampl. São Paulo: Editora Revista dos Tribunais, 2008, p. 116.

104 GRECO, Op. Cit., p. 109.

105 PAZ, Isabel Sánches García de. Función político-criminal del delito de asociación para delinquir:desde el Derecho Penal político hasta la lucha contra el crimen organizado. Disponível em: <https://www.cienciaspenales.net/descargas/idp_docs/doctrinas>. Acessado em 08 mar. 2010, p. 669.

106 Idem, p. 672-673.

107 No original: "quien... pena por hechos futuros, ya no tiene razón alguna para dejar impunes los pensamientos" (MELIÁ, 2008, p. 37).

Artigo recebido em: 10/03/2010

Aprovado para publicação em: 17/03/2010 